\title{
Pancreatic islet cell transplantation
}

\author{
Mine Ün ${ }^{1} \mathbb{D}$, Oytun Erbaş² \\ ${ }^{1}$ Istanbul Aydin University Medical Faculty, Istanbul, Turkey \\ ${ }^{2}$ Department of Physiology, Demiroğlu Bilim University Faculty of Medicine, Istanbul, Turkey
}

\begin{abstract}
Type 1 Diabetes mellitus is an autoimmune disease characterized by the destruction of insulin-producing beta cells in the pancreas. These patients become dependent on external insulin because they cannot produce insulin. However, in the long-term, exogenous insulin treatment does not prevent diabetic complications. In order to find an alternative diabetic treatment, clinical studies have demonstrated that pancreas transplantation or purified pancreatic islet transplantation could maintain control over blood sugar levels in Type 1 diabetes patients and were more effective treatment methods for these patients. Pancreatic islet transplantation is carried out with a smaller transplantation mass compared to complete pancreas transplantation. This also allows a more minor operation and transplantation of less immunologic tissue. Therefore, new methods aim to improve pancreatic islet transplantation.
\end{abstract}

Keywords: Beta cells, pancreatic islet transplantation, type 1 diabetes mellitus.

\section{INSULIN HORMONE}

Energy is the body's most basic necessity in order to maintain life. Through a hormone called insulin produced by beta cells in the pancreas, sugar (glucose) acquired from ingested food or excreted to the blood from the stores in the liver enters cells and is converted into the energy required for the body. ${ }^{[1-3]}$

Blood sugar decreases when it enters cells. That is, insulin is the main hormone to decrease blood sugar. The beta cells of the pancreas continually control blood sugar and release insulin when the body needs it..$^{[1-3]}$

\section{TYPE 1 DIABETES MELLITUS}

The autoimmune disease in which the pancreatic Langerhans islet beta cells are deemed foreign and eliminated by the body's defense cells is called type 1 diabetes mellitus. In type 1 diabetes, destruction of beta cells renders the body unable to produce insulin and becomes dependent on external insulin intake..$^{[4,5]}$

Type 1 diabetes is a disease of increasing prevalence which reduces quality of life and life expectancy and may threaten vital organs with complications such as chronic hyperglycemia, nephropathy, retinopathy, and neuropathy. ${ }^{[4-8]}$

In order to maintain blood sugar levels, patients with type 1 diabetes require external insulin intake. Banting and Best's discovery of insulin in the early 1920s was revolutionary. Diabetes, which previously caused rapid mortality, became preventable with this discovery. ${ }^{[7-10]}$

Insulin injection is used to delay or even prevent the occurrence of complications such as nephropathy, neuropathy, and retinopathy in the short-term, however, in the long-term, these patients may develop chronic diabetic complications (nonhealing wounds, renal failure, blindness, cardiovascular diseases, etc.) which worsen over time..$^{[4,5,7,11]}$ 
In other words, external insulin intake is inadequate. Clinical studies have shown that pancreas or purified pancreas islet transplantation may ensure blood sugar control in type 1 diabetes patients and are more effective treatment methods. ${ }^{[12-14]}$

\section{PANCREAS TRANSPLANT}

Pancreas transplantation is the most effective form of treatment in type 1 diabetes. However, pancreas transplantation is a major surgical procedure. It is also difficult to find a compatible pancreas, and in order to prevent organ rejection, recipients must use immunosuppressant's for the continuation of their lives, which has relatively harmful effects. Therefore, pancreas transplantation is only performed on end stage diabetic patients who have developed type 1 diabetes-related renal failure or other serious complications. ${ }^{[12,14]}$

\section{PANCREAS ISLET (BETA CELL) TRANSPLANTATION}

The best alternative to pancreas organ transplantation in type 1 diabetes is pancreas islet transplantation. ${ }^{[7,13,15]}$

Since Langerhans islets in the pancreas contain insulin-producing beta cells, transplantation of these islets alone is a relatively interesting approach to type 1 diabetes. Islets account for only $1-2 \%$ of the pancreas, and is therefore a much smaller transplantation mass compared to complete pancreas transplant. This allows for a more minor surgical operation and transplantation of less immunological tissue..$^{[7,13,15]}$

Another advantage of islet transplant is that healthy islets can be isolated from donor pancreas even when the entire pancreas is unsuitable for transplantation. ${ }^{[12,15]}$

\section{ISLET TRANSPLANT STUDIES}

For the first time in 1967, Paul Lacy developed a new collagenase-based method for pancreas islet isolation in rats. The method was further modified by Dr. Camillo Ricordi, who worked together with Lacy to successfully isolate islets in in vitro and in vivo experiments. ${ }^{[16-29]}$

The first successful animal models for successful islet transplantation was published in the 1960s-1970s. Studies demonstrated how the transplanted islets prevented diabetes in both rodents and nonhuman primates. ${ }^{[19,20,28,29]}$

In the 1970s and 1980s, successful animal models were attempted in humans. However, since pancreas islets are structurally different in humans compared to small animals (rats, guinea pigs, etc.), methods used to isolate islet cells in small cells were ineffective when applied in humans. Therefore, these methods were aimed to be adapted for humans. ${ }^{[21,28,29]}$

In the mid-1980s, the first human islet transplantation was performed. Initial attempts at islet transplantation had relatively low success rates. According to studies, transplanted islets were able to prevent diabetes after one year of insulin synthesis in only one out of 10 patients. ${ }^{[7,21,22,28,29]}$

In the late 1990s, despite developments with continuing transplants, only about $10 \%$ of recipients were able to achieve normal blood sugar (euglycemia). ${ }^{77,22,28,29]}$

In later years, yearly islet transplantation success rates leaped from 10 to $50 \%$ with advancements in islet isolation and purification techniques. In other words, at least half of patients who underwent islet transplantation achieved insulin independence in over a year. ${ }^{[7,21,22,28,29]}$

In following years, more successful islet transplantations were performed. The most important of these transplantations were performed in 2000 by Dr. James Shapiro et al. ${ }^{[22]}$ at the Alberta University Diabetes Institute in Edmonton, Canada. By using islets from multiple donors, transplantation was conducted in seven type 1 diabetes patients and all seven patients achieved normal blood sugar levels without exogenous insulin use over the period of one year. In this manner, annual insulin independence rate attained 100\% with the Edmonton method. ${ }^{[22,28]}$

By introducing the world to the clinical method to be known as the Edmonton protocol, James Shapiro et al. ${ }^{[22]}$ achieved a revolutionary achievement in islet transplantation studies. ${ }^{[28]}$

This protocol was adapted by islet transplantation centers worldwide and greatly increased the success rates of islet transplantation. ${ }^{[7,28]}$ 


\section{HOW ARE ISLETS TRANSPLANTED?}

The pancreas required for pancreas islet transplant is obtained from persons who have undergone brain death and islet cells are obtained during a 6 to 8-hour long process of enzymatic degradation of the pancreas and extraction of beta cells. Currently, relatively pure islet cell preparations can be obtained with collagenase digestion of the pancreas, followed by the use of Ficoll-Conray discontinuous gradient for the separation of isolated islets. ${ }^{[13,28,29]}$

With many special drug combinations that prevent organ rejection (sirolimus, tacrolimus, daclizumab), isolated beta cells are transferred to the liver through a catheter attached to the portal vein (the main vessel that carries blood from the intestines to the liver) under local anesthesia. The islets of insulin that are transported to the liver begin to secrete insulin to regulate blood sugar (Figure 1). ${ }^{[7,28]}$

Although islet transplantation to the liver (Edmonton method) may seem like it would have long-term effect, studies by the same authors showed that islets transplanted to the liver lost function within the first few years, and most patients require repeated injections after five years. ${ }^{[7,23]}$

Studies have leaned towards comprehending why islets lose function in the liver. After administration to the portal vein, the islets reach the liver and must adapt to it, however, they are faced with negative conditions. Immediately after administration to the vein, islets are exposed to higher levels of drugs and nutrients such as glucose in the portal system compared to the peripheral circulation, causing loss of islet function. ${ }^{[24]}$

It should also be known that immunosuppressant drugs used by the recipients are another one of the main causes of function loss in transplanted islets. ${ }^{[7,23,24]}$

\section{DISADVANTAGES OF ISLET TRANSPLANTATION}

Although islet transplantation seems easy, there are serious difficulties in isolating beta cells from the pancreas without harming islets. In addition, a considerable number of islets must be transplanted in order to maintain blood glucose levels for a long period of time. Since islets cannot be extracted without completely harming all of them, a single transplantation requires at least two human donor pancreases. Furthermore, islet transplantations must be repeated more than once. ${ }^{[7,25,26]}$

Even if a large number of islets are successfully transplanted, the recipient's immune system attacks the transplanted beta cells. Therefore, the patient's immune system must be suppressed.

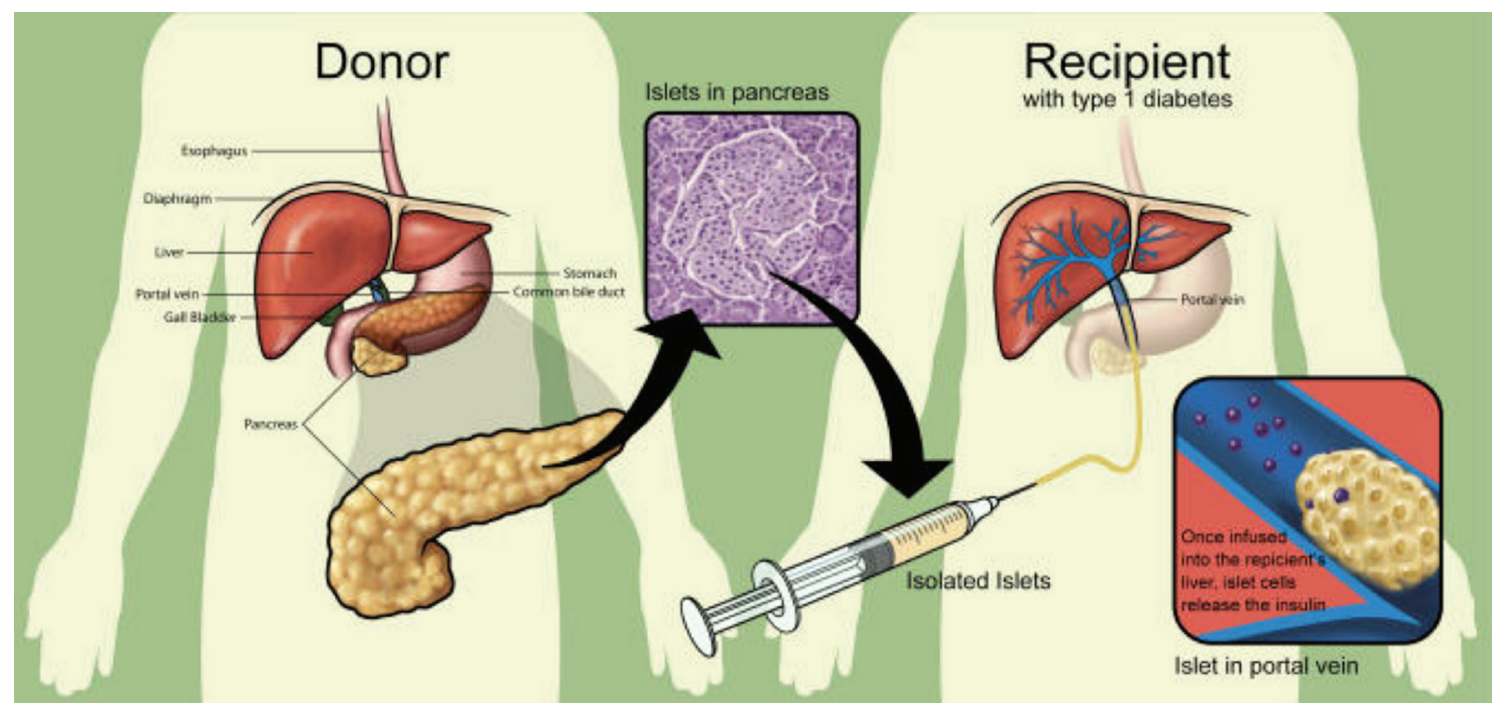

Figure 1. Edmonton method. Beta cells isolated from the donor's pancreas are injected to the recipient's portal vein. These cells settle in the liver and begin to produce insulin. ${ }^{[7]}$ 


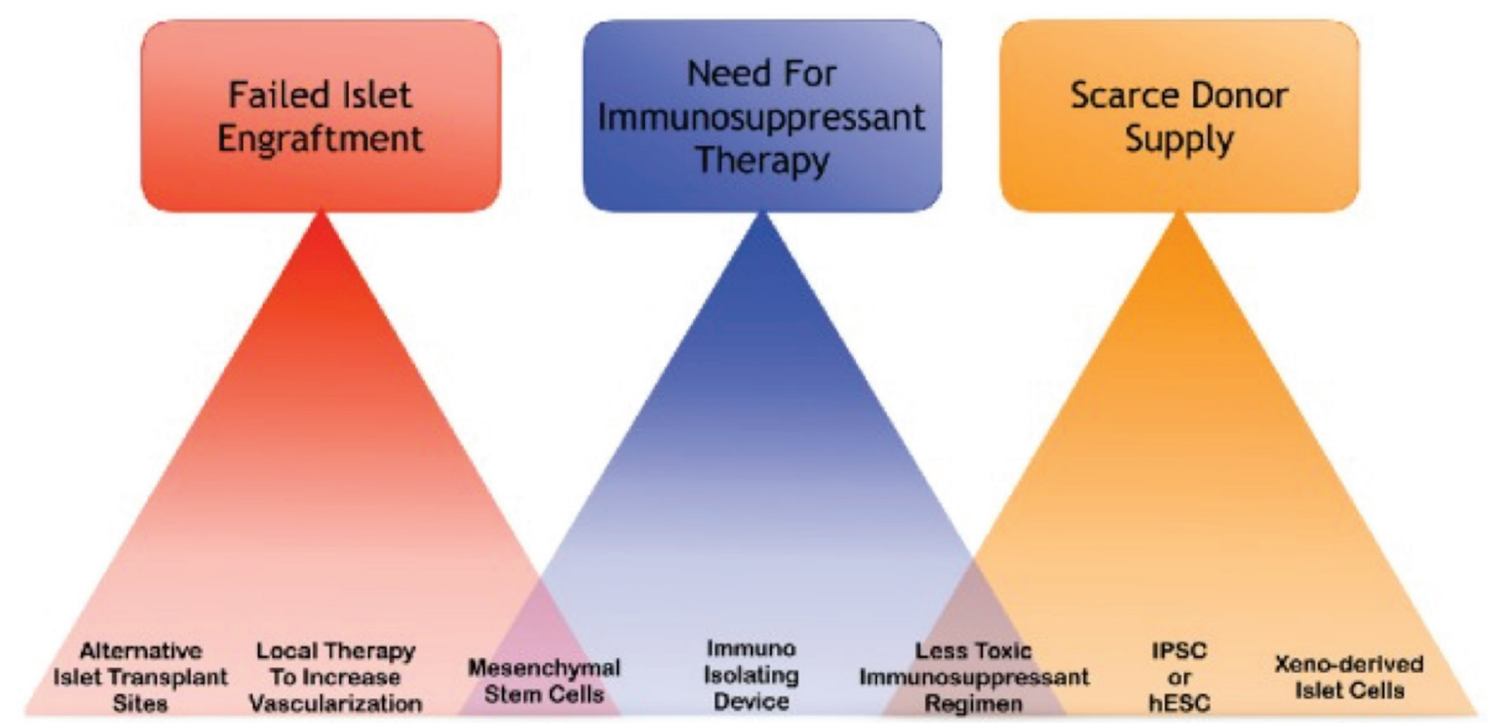

Figure 2. Disadvantages of islet transplantation and methods of prevention. ${ }^{[27]}$

As in all transplantation procedures, recipients are required to use immunosuppressants for the rest of their life after islet transplantation. High doses of immunosuppressive drugs are also harmful (Figure 2). ${ }^{[7,27-29]}$

Therefore, it is necessary to develop new methods to protect the transplanted islets from prolonged destruction in the body and keep them alive longer without the use of immunosuppressive drugs which have the potential to cause serious side effects in patients. ${ }^{[30]}$

\section{NEW METHODS TO INCREASE ISLET CELL LONGETIVITY}

There have been significant developments in islet transplantation over the last 10 years. ${ }^{\text {[1-33] }}$

It has been understood that one of the reasons transplanted cells undergo rapid destruction with the Edmonton method is that they are transplanted to the liver, which contains high levels of toxic drugs. Therefore, researchers have studied alternative regions to transplant the islets. Studies investigating transplantation into regions such as arm muscle, spleen, renal capsule, and bone marrow have found longer prolonged vitality of the islets in these regions. ${ }^{[34-36]}$

In ongoing studies, it is aimed to transplant islets without immunosuppressive drugs. In one of the first methods developed to transplant islets without immunosuppressive drugs, islets are first encapsulated with materials to protect them from external factors (encapsulation) and then transplanted to recipients (Figure 3). ${ }^{[28,29,37]}$

These studies aim to protect the islets from the recipient's immune system by encapsulating them with an encasement. However, this time, the immune system develops tissue inflammation against the encapsulation material. These encapsulation studies on islet transplantation have been unsuccessful. ${ }^{[28.29,37]}$

Researchers who realized they could not protect the islets from the immune defense system later attempted to transplant islets into regions with the least amount of immune response. With this purpose in mind, islet transplantation was attempted in regions such as the brain, thymus, and testes, rather than the liver. However, these transplantations were also unsuccessful because of the toxic molecules excreted by the molecules of the tissue cells themselves. It was later thought that it would be more reasonable to introduce the corresponding molecules synthesized in these tissues into the islets prior to transplantation by gene transfer instead of transferring the islets to these regions. ${ }^{[28,29,38]}$

After the idea of gene transplants to the islets, the human gene TRAIL (TNF Related Apoptosis 


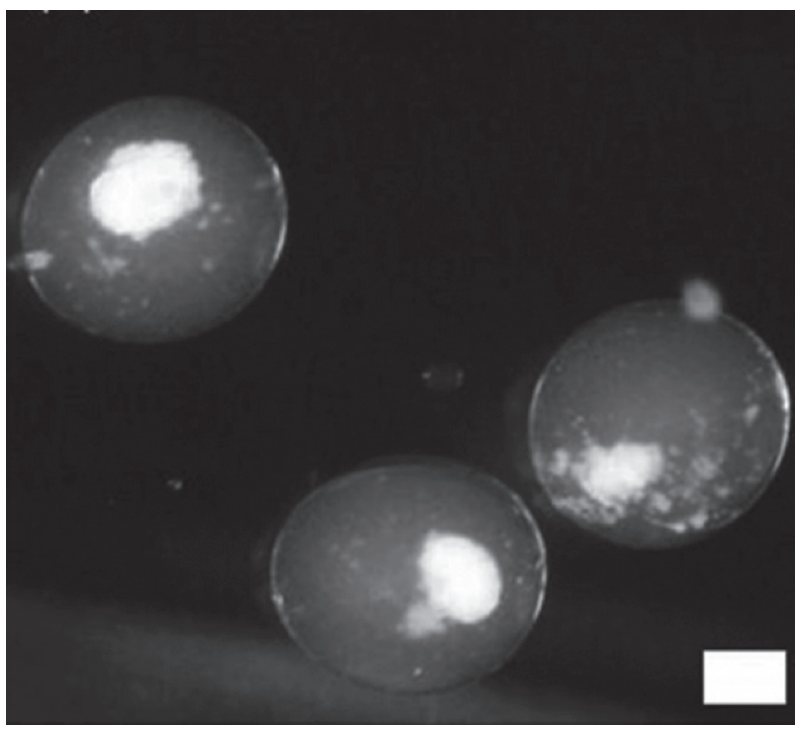

Figure 3. Encapsulation. Islets are transplanted to the recipient after being encapsulated by materials capable of protecting them from the recipient's immune system. ${ }^{28]}$

Inducing Ligand) came to mind. This gene has the ability to suppress the immune system of the recipient. With this aim, a large number of islets were isolated from the pancreases of rats. The TRAIL gene was transferred to islets with adenovirus, which is a suitable vector for gene transfer (Adenovirus is the most commonly used gene vector in clinical gene therapy trials today). ${ }^{[39-48]}$

Later, two groups of rats with Streptozotocininduced type 1 diabetes were surgically transplanted with islets with and without gene transfer under their renal capsules. Rats with islet transplantations without gene transfer had normal blood sugar levels for a short period of time which later reelevated. Increased blood sugar showed that the transplanted islets were eventually rejected. Islet transplantation after gene transfer, however, maintained normal blood sugar levels for a longer period of time compared to transplantation without gene transfer. In addition, renal sections of rats with gene-transferred islets showed a significantly lower rate of immune cells compared to those without gene transfer. This study demonstrated that transferred genes protected the islets from the recipient's immune system and that none of these rats were administered immunosuppressive drugs. ${ }^{[4-48]}$ That study prevented gene-transferred transplanted islets from being damaged by the recipient's immune system. This method only provides protection to islets in the transplantation region with gene transfer. ${ }^{[43-48]}$

In conclusion, studies on pancreas islet transplantation are rapidly advancing and this suggests that significant findings on this subject will be discovered in the future. ${ }^{[43-49]}$

\section{Declaration of conflicting interests}

The authors declared no conflicts of interest with respect to the authorship and/or publication of this article.

\section{Funding}

The authors received no financial support for the research and/or authorship of this article.

\section{REFERENCES}

1. Plum L, Belgardt BF, Brüning JC. Central insulin action in energy and glucose homeostasis. $\mathrm{J}$ Clin Invest 2006;116:1761-6.

2. Matthews DR, Hosker JP, Rudenski AS, Naylor BA, Treacher DF, Turner RC. Homeostasis model assessment: insulin resistance and beta-cell function from fasting plasma glucose and insulin concentrations in man. Diabetologia 1985;28:412-9.

3. Gerozissis K. Brain insulin, energy and glucose homeostasis; genes, environment and metabolic pathologies. Eur J Pharmacol 2008;585:38-49.

4. Kerner W, Brückel J. Definition, klassifikation und diagnostik des diabetes mellitus. Diabetologie und Stoffwechsel 2010;5(S 02):S109-S12.

5. Klöppel G, Löhr M, Habich K, Oberholzer M, Heitz PU. Islet pathology and the pathogenesis of type 1 and type 2 diabetes mellitus revisited. Surv Synth Pathol Res 1985;4:110-25.

6. Wild S, Roglic G, Green A, Sicree R, King H. Global prevalence of diabetes: estimates for the year 2000 and projections for 2030. Diabetes Care 2004;27:1047-53.

7. Naftanel MA, Harlan DM. Pancreatic islet transplantation. PLoS Med. 2004;1:e58.

8. Diabetes Control and Complications Trial Research Group, Nathan DM, Genuth S, Lachin J, Cleary P, Crofford $\mathrm{O}$, et al. The effect of intensive treatment of diabetes on the development and progression of long-term complications in insulin-dependent diabetes mellitus. N Engl J Med 1993;329:977-86.

9. Epidemiology of Diabetes Interventions and Complications (EDIC). Design, implementation, and preliminary results of a long-term follow-up of the Diabetes Control and Complications Trial cohort. Diabetes Care 1999;22:99-111.

10. Writing Team for the Diabetes Control and Complications Trial/Epidemiology of Diabetes Interventions and Complications Research Group. 
Sustained effect of intensive treatment of type 1 diabetes mellitus on development and progression of diabetic nephropathy: the Epidemiology of Diabetes Interventions and Complications (EDIC) study. JAMA 2003;290:2159-67.

11. Lim DJ, Antipenko SV, Anderson JM, Jaimes KF, Viera L, Stephen BR, et al. Enhanced rat islet function and survival in vitro using a biomimetic self-assembled nanomatrix gel. Tissue Eng Part A 2011;17:399-406.

12. Poggioli R, Faradji RN, Ponte G, Betancourt A, Messinger S, Baidal DA, et al. Quality of life after islet transplantation. Am J Transplant 2006;6:371-8.

13. Sutherland DE, Matas AJ, Najarian JS. Pancreatic islet cell transplantation. Surg Clin North Am 1978;58:365-82.

14. Venstrom JM, McBride MA, Rother KI, Hirshberg B, Orchard TJ, Harlan DM. Survival after pancreas transplantation in patients with diabetes and preserved kidney function. JAMA 2003;290:2817-23.

15. Shapiro AM, Pokrywczynska M, Ricordi C. Clinical pancreatic islet transplantation. Nat Rev Endocrinol 2017;13:268-77.

16. Lacy PE, Kostianovsky M. Method for the isolation of intact islets of Langerhans from the rat pancreas. Diabetes 1967;16:35-9.

17. Ballinger WF, Lacy PE. Transplantation of intact pancreatic islets in rats. Surgery 1972;72:175-86.

18. Lillehei RC, Idezuki Y, Kelly WD, Najarian JS, Merkel FK, Goetz FC. Transplantation of the intestine and pancreas. Transplant Proc 1969;1:230-8.

19. Kemp CB, Knight MJ, Scharp DW, Lacy PE, Ballinger WF. Transplantation of isolated pancreatic islets into the portal vein of diabetic rats. Nature 1973;244:447.

20. Scharp DW, Murphy JJ, Newton WT, Ballinger WF, Lacy PE. Transplantation of islets of Langerhans in diabetic rhesus monkeys. Surgery 1975;77:100-5.

21. Ricordi C, Lacy PE, Finke EH, Olack BJ, Scharp DW. Automated method for isolation of human pancreatic islets. Diabetes 1988;37:413-20.

22. Shapiro AM, Lakey JR, Ryan EA, Korbutt GS, Toth E, Warnock GL, et al. Islet transplantation in seven patients with type 1 diabetes mellitus using a glucocorticoid-free immunosuppressive regimen. $\mathrm{N}$ Engl J Med 2000;343:230-8.

23. Ryan EA, Paty BW, Senior PA, Bigam D, Alfadhli E, Kneteman NM, et al. Five-year follow-up after clinical islet transplantation. Diabetes 2005;54:2060-9.

24. Harlan DM, Kenyon NS, Korsgren O, Roep BO; Immunology of Diabetes Society. Current advances and travails in islet transplantation. Diabetes 2009;58:2175-84.

25. Shapiro AM, Ricordi C, Hering BJ, Auchincloss H, Lindblad R, Robertson RP, et al. International trial of the Edmonton protocol for islet transplantation. $\mathrm{N}$ Engl J Med 2006;355:1318-30.

26. Langer RM. Islet transplantation: lessons learned since the Edmonton breakthrough. Transplant Proc 2010;42:1421-4.
27. Gamble A, Pepper AR, Bruni A, Shapiro AMJ. The journey of islet cell transplantation and future development. Islets 2018;10:80-94.

28. Farney AC, Sutherland DE, Opara EC. Evolution of Islet Transplantation for the Last 30 Years. Pancreas 2016;45:8-20.

29. Ramírez-Domínguez M. Historical Background of Pancreatic Islet Isolation. Adv Exp Med Biol 2016;938:1-9.

30. Ryan EA, Lakey JR, Paty BW, Imes S, Korbutt GS, Kneteman NM, et al. Successful islet transplantation: continued insulin reserve provides long-term glycemic control. Diabetes 2002;51:2148-57.

31. Linetsky E, Bottino R, Lehmann R, Alejandro $\mathrm{R}$, Inverardi L, Ricordi C. Improved human islet isolation using a new enzyme blend, liberase. Diabetes 1997;46:1120-3.

32. Bucher $\mathrm{P}$, Mathe Z, Morel P, Bosco D, Andres A, Kurfuest $\mathrm{M}$, et al. Assessment of a novel twocomponent enzyme preparation for human islet isolation and transplantation. Transplantation 2005;79:91-7.

33. Emamaullee JA, Stanton L, Schur C, Shapiro AM. Caspase inhibitor therapy enhances marginal mass islet graft survival and preserves long-term function in islet transplantation. Diabetes 2007;56:1289-98.

34. Merani S, Toso C, Emamaullee J, Shapiro AM. Optimal implantation site for pancreatic islet transplantation. Br J Surg 2008;95:1449-61.

35. Daly B, O'Kelly K, Klassen D. Interventional procedures in whole organ and islet cell pancreas transplantation. Semin Intervent Radiol 2004;21:335-43.

36. Campbell PM, Senior PA, Salam A, Labranche K, Bigam DL, Kneteman NM, et al. High risk of sensitization after failed islet transplantation. Am J Transplant 2007;7:2311-7.

37. Johansson U, Rasmusson I, Niclou SP, Forslund N, Gustavsson L, Nilsson B, et al. Formation of composite endothelial cell-mesenchymal stem cell islets: a novel approach to promote islet revascularization. Diabetes. 2008;57:2393-401.

38. Sanlioglu AD, Griffith TS, Omer A, Dirice E, Sari R, Altunbas HA, et al. Molecular mechanisms of death ligand-mediated immune modulation: a gene therapy model to prolong islet survival in type 1 diabetes. $\mathrm{J}$ Cell Biochem 2008;104:710-20.

39. Sanlioglu AD, Dirice E, Elpek O, Korcum AF, Balci MK, Omer A, et al. High levels of endogenous tumor necrosis factor-related apoptosis-inducing ligand expression correlate with increased cell death in human pancreas. Pancreas 2008;36:385-93.

40. Sanlioglu AD, Dirice E, Elpek O, Korcum AF, Ozdogan M, Suleymanlar I, et al. High TRAIL death receptor 4 and decoy receptor 2 expression correlates with significant cell death in pancreatic ductal adenocarcinoma patients. Pancreas 2009;38:154-60.

41. Holoch PA, Griffith TS. TNF-related apoptosisinducing ligand (TRAIL): a new path to anti-cancer 
therapies. Eur J Pharmacol 2009;625:63-72.

42. Kahraman S, Dirice E, Sanlioglu AD, Yoldas B, Bagci $\mathrm{H}$, Erkilic $\mathrm{M}$, et al. In vivo fluorescence imaging is well-suited for the monitoring of adenovirus directed transgene expression in living organisms. Mol Imaging Biol 2010;12:278-85.

43. Lopez-Talavera JC, Garcia-Ocaña A, Sipula I, Takane KK, Cozar-Castellano I, Stewart AF. Hepatocyte growth factor gene therapy for pancreatic islets in diabetes: reducing the minimal islet transplant mass required in a glucocorticoid-free rat model of allogeneic portal vein islet transplantation. Endocrinology 2004;145:467-74.

44. Dirice E, Sanlioglu AD, Kahraman S, Ozturk S, Balci MK, Omer A, et al. Adenovirus-mediated TRAIL gene (Ad5hTRAIL) delivery into pancreatic islets prolongs normoglycemia in streptozotocin-induced diabetic rats. Hum Gene Ther 2009;20:1177-89.
45. Ahrén B, Pacini G. Islet adaptation to insulin resistance: mechanisms and implications for intervention. Diabetes Obes Metab 2005;7:2-8.

46. Dirice E, Kahraman S, Elpek GO, Aydin C, Balci MK, Omer A, et al. TRAIL and DcR1 expressions are differentially regulated in the pancreatic islets of STZ- versus CY-applied NOD mice. Exp Diabetes Res 2011;2011:625813.

47. Shapiro AM, Lakey JR. Future trends in islet cell transplantation. Diabetes Technol Ther 2000;2:449-52.

48. Kahraman S, Dirice E, Hapil FZ, Ertosun MG, Ozturk S, Griffith TS, et al. Tracing of islet graft survival by way of in vivo fluorescence imaging. Diabetes Metab Res Rev 2011;27:575-83.

49. Ahearn AJ, Parekh JR, Posselt AM. Islet transplantation for Type 1 diabetes: where are we now? Expert Rev Clin Immunol 2015;11:59-68. 